\title{
Physical mapping of three fruit ripening genes: En- dopolygalacturonase, ACC oxidase and ACC synthase from apple (Malus $x$ domestica) in an apple rootstock A106 (Malus sieboldii)
}

\author{
ZHU JI M E I *1, SE GARDINER**, M LAY-YEE* \\ The Horticulture and Food Research Institute of New \\ Zealand Ltd \\ ${ }^{*}$ Mt Albert Research Centre Private Bag 92169, Auckland, \\ New Zealand \\ **Batchelar Research Centre, Private Bag 11030, Palmer- \\ ston North, New Zealand
}

\section{ABSTRACT}

The apple rootstock, A106 (Malus sieboldii), had 17 bivalents in pollen mother cells at meiotic metaphase 1 , and 17 chromosomes in a haploid pollen cell. Karyotypes were prepared from root-tip cells with $2 \mathrm{n}=34$ chromosomes. Seven out of 82 karyotypes (8.5\%) showed one pair of satellites at the end of the short arm of chromosome 3. C-bands were shown on 6 pairs of chromosomes 2, 4, $6,8,14$, and 16 near the telomeric regions of short arms. Probes for three ripening-related genes from Malus x domestica: endopolygalacturonase (EPG, $0.6 \mathrm{~kb}$ ), ACC oxidase (1.2 kb), and ACC synthase ( $2 \mathrm{~kb}$ ) were hybridized in situ to metaphase chromosomes of A106. Hybridization sites for the EPG gene were observed on the long arm of chromosome 14 in 15 out of 16 replicate spreads and proximal to the centromere of chromosomes 6 and 11. For the ACC oxidase gene, hybridization sites were observed in the telomeric region of the short arm of chromosomes 5 and 11 in $87 \%$ and $81 \%$ of 16 spreads respectively, proximal to the centromere of chromosome 1 in $81 \%$ of the spreads, and on the long arm of chromosome 13 in 50\% of the spreads.

1. Corresponding author 
Twenty five spreads were studied for tile ACC synthase gene and hybridization sites were observed in the telomeric region of the short arm of chromosome 12 in $96 \%$ of the spreads, chromosomes 9 and 10 in $76 \%$ of the spreads, and chromosome 17 in $56 \%$ of the spreads.

Key words: Malus, chromosome, in situ hybridization C-banding, karyotype.

\section{INTRODUCTION}

In situ hybridization of DNA probes to chromosomes using non-radioactive detection systems has been used in a number of crops including wheat [1], pea[2-4], and apple[5]. The physical mapping of genes in apple is part of an international effort to map the apple genome[6-8].

This paper describes the karyotype of an apple rootstock cultivar A106 (Malus sieboldii) which has been characterised by analysis of the meiotic metaphase I chromosomes, somatic mitoses and C-banding pattern. Probes for three ripening-related genes (endopolygalacturonase (EPG), ACC oxidase, and ACC synthase from Malus $\mathrm{x}$ domestica) were hybridized in situ to the metaphase chromosomes spreads of A106 in order to locate the physical position of the corresponding genes on an apple karyotype.

\section{MATERIALS AND METHODS}

\section{Plant material}

Young branches of the apple rootstock A106 (Malus sieboldii) were cut, planted in pots and kept in a green house for several weeks before being transfered outdoors to initiate the growth of young roots for use in mitotic chromosome spreads.

\section{Cytogenic studies}

Meiotic analysis

Flower-buds of A106 were harvested just as they emerged from the very young leaf sheath in September for use in the preparation of meiotic chromosome spreads. Meiotic chromosome counts were performed by following the procedure of Lespinasse et al[9]. Young flower buds were fixed in a Carnoy solution (6:3:1 absolute ethanol:chloroform:glacial acetic acid) mordanted with a few drops of ferric chloride solution and stored at $4{ }^{\circ} \mathrm{C}$ overnight or a few days before use. Meiotic spreads were prepared by squashing pollen mother cells in a drop of Acetocarmine staining solution. Chromosome spreads of cells in metaphase 1 were examined for chromosome structure and the presence of bivalents.

\section{Preparation of mitotic chromosome spreads}

Mitotic chromosome spreads from young root-tips of A106 were prepared according to Zhu and Gardiner[5]. Giemsa staining was carried out according to the method of Schweizer[10] and well separated mitotic chromosome spreads were recorded and photographed under an oil immersion 100 


\section{Zhu JM et al}

$\mathrm{x}$ objective using a Zeiss Carol microscope. These chromosome spreads were used for C-banding and the in situ hybridization studies as described below.

\section{Chromosome C-banding}

Mitotic slides were aged at room temperature for 3-10 d. The protocol for C-banding was carried out by a modified procedure derived from Summer[11], Seal and Bennet[12], Kakeda et al[13], Heneen and Brismar[14] and MacGregor and Varley[15]. The protocol was as follows. The aged slides were denatured in a fleshly prepared $5 \% \mathrm{Ba}(\mathrm{OH})_{2}$ solution at $60^{\circ} \mathrm{C}$ for $30 \mathrm{~min}$. Following washing in distilled water at room temperature, slides were renatured in $2 \times$ SSC (SSC: $0.15 M$ sodium chloride and $0.015 \mathrm{M}$ sodium citrate) at $60^{\circ} \mathrm{C}$ for $2 \mathrm{~h}$. One of two alternative procedures was then followed for staining. In the first procedure slides were rinsed in distilled water, and then stained in $5 \%$ Wright's solution[12] for 1-2 $\mathrm{h}$ at room temperature. In the second procedure slides were immediately dipped in $0.02 \%$ trypsin (Difco Bacto-trysin) for $30 \mathrm{~min}$, rinsed in distilled water for $2 \mathrm{~min}$ at room temperature and stained in 5\% Wright's solution. If the C-bands were not sharp enough, slides were destained in 95\% ethanol for $5 \mathrm{~min}$, dried in air, retreated with trypsin for 20-30 min at room temperature, rinsed in distilled water and restained in 5\% Wright solution or Giemsa solution.

\section{Probe preparation}

Primers for a Prunus endopolygalacturonase were obtained from G. King, Horticulture Research International, Wellesbourne, England. Sequences were:

GK5 5' -ACT TGT GGA CCA GGC CAT GGA

GK6 5'-CAC ATT TTT CAC TTG AAC TGC.

These primers were used to amplify DNA from Malus $x$ domestica cv. 'Scijoy' with reaction conditions similar to those for probe synthesis (see below), but lacking added $\mathrm{MgCl}_{2}$ and with the addition of $1.5 \%$ formamide. The products were electrophoresed in a $2 \%$ agarose gel and the major product of $0.6 \mathrm{~kb}$ was excised and purified using Prep-a-Gene (Biorad, Hercules, Ca, USA). An aliquot of this was employed as template for the synthesis of biotin labelled probe. The $1.2 \mathrm{~kb}$ ACC oxidase clone[16] and the $2 \mathrm{~kb}$ ACC synthase clone[17] were isolated from a cDNA library prepared in pSPORT from polyA+ RNA extracted from ripe apple cortical tissue.

Biotin-labelled probe was prepared by the method of Emanuel[18] using 40 cycles of PCR amplication reaction in a thermal cycler (Perkin Elmer Cetus). The first cycle consisted of 4 min at $94^{\circ} \mathrm{C}, 1 \mathrm{~min}$ at $55^{\circ} \mathrm{C}$, and $2 \mathrm{~min}$ at $72^{\circ} \mathrm{C}$. The second and subsequent cycles were $1 \mathrm{~min}$ at $94^{\circ} \mathrm{C}$, $1 \mathrm{~min}$ at $55^{\circ} \mathrm{C}$, and $2 \mathrm{~min}$ at $72^{\circ} \mathrm{C}$, with $8 \mathrm{~min}$ extension time at $72^{\circ} \mathrm{C}$ after the final cycle. An additional 5 units of Taq polymerase (Stratagene, La Jolla, Ca, USA) was added after the 20th cycle.

Each PCR reaction (100 $\mu 1)$ contained 5 units of Taq polymerase (Stratagene), 5-20 ng DNA template, 5:1 of dNTP (containing $2 \mathrm{mM}$ dCTP, dATP, dGTP; $1.34 \mathrm{mM}$ dTTP; 0. $66 \mathrm{mM}$ biotin16-dUTP (Boehringer)), $6.3 \mathrm{ng}$ SP6 promoter primer and $6.7 \mathrm{ng}$ T7 promoter primer, $4 \mu \mathrm{l}$ of 12.5 $\mathrm{mM}$ of $\mathrm{MgCl}_{2}, 10: 1$ of $10 \times$ PCR reaction buffer as supplied by the manufacturer $(100 \mathrm{mM}$ Tris-HCl $\mathrm{pH} 8.8,500 \mathrm{mM} \mathrm{KCl}, 1.5 \mathrm{mM} \mathrm{MgCl}, 0.1 \%$ gelatin) and $\mathrm{H}_{2} \mathrm{O}$ to a final volume of $100 \mu \mathrm{l}$. Each of the ripening-related genes was labelled individually and the probes were purified using Prep-aGene (Biorad) after checking by agarose gel electrophoresis that a single band of the correct size had been synthesized. Biotin label quantitation using Dot Blot was carried out according to the manufacturer's instructions ( "BluGENE” , Life Technologies, Bethesda, Md, USA).

\section{In situ hybridization}

Prior to hybridizations, mitotic slides prepared from young root tips were processed through a series of treatments. Slides (stored at $-70^{\circ} \mathrm{C}$ ) were refixed in 1:3 acetic acid: $95 \%$ ethanol for $1 \mathrm{~h}$, transfered to $95 \%$ ethanol and then to absolute ethanol (5 min each step) and dried in air for 5-10 min. Slides were treated with DNase-free RNase $(100 \mu \mathrm{g} / \mathrm{ml}$ in $2 \times$ SSC) for $60 \mathrm{~min}$ at $37^{\circ} \mathrm{C}$, rinsed briefly in $2 \times \mathrm{SSC}$ at room temperature, and then treated with $50 \mu \mathrm{lof} 40 \mathrm{mg} / \mathrm{ml}$ 


\section{Physical mapping of three fruit ripening genes in an apple rootstock A106}

proteinase $\mathrm{K}$ (Sigma) in PBS buffer, covered with a coverslip at $37^{\circ} \mathrm{C}$ for $20 \mathrm{~min}$, refixed in a freshly prepared 4\% paraformaldehyde in PBS buffer at room temperature for $1 \mathrm{~min}$, dehydrated by serial ethanol immersions (70\%, 90\%, and 100\% ethanol, 3 min each) and dried in air for 5-10 min. The in situ hybridization of three biotinylated cDNA probes (EPG, ACC oxidase and ACC synthase genes) were performed according to manufacturer's instructions (BRL, Life Technologies). The hybridization solution contained 50\% formamide, $2 \times$ SSC, $10 \%$ dextran sulphate, $1 \times$ Denhardts solution (BRL Life Technologies) and $10 \mu \mathrm{g} / \mathrm{ml}$ of biotinylated PCR product. Twenty to thirty microliters of this hybridization mixture was applied onto each slide. Each slide was covered with a siliconised coverslip, placed onto a preheated plate at $100^{\circ} \mathrm{C}$ for $5 \mathrm{~min}$, and then immediately quenched on ice for 3-5 min. Following sealing of the coverslip onto the slide with rubber cement, the hybridization was performed at $42^{\circ} \mathrm{C}$ overnight. The coverslips were removed carefully and slides were washed 4 times in $0.2 \times \mathrm{SSC}$ at $42^{\circ} \mathrm{C}(3-4 \mathrm{~min})$ and 3 times in $0.2 \times \mathrm{SSC}$ at room temperature $(5 \mathrm{~min})$. The biotinylated hybridization signal was detected using the streptavidin conjugated alkaline phosphatase in conjugate dilution buffer (100 mM Tris- $\mathrm{HCl}, 150 \mathrm{mM} \mathrm{MgCl}, 10$ $\mathrm{mg} / \mathrm{ml}$ bovine serum albumin) according to manufacturer's instructions (BRL, Life Technologies). The alkaline phosphatase was visualized by incubating the slide at $37^{\circ} \mathrm{C}$ in a chromogenic substrate solution. This substrate solution consists of $200 \mu 1$ of nitro blue tetrazolium $(75 \mathrm{mg} / \mathrm{ml}$ dissolved in $70 \%$ (v/v) dimethylformamide) and $166 \mu 1$ of 4-bromo-5-chloro-3-indolylphospate $(50 \mathrm{mg} / \mathrm{ml}$ dissolved in $100 \%$ dimethylformamide) in $50 \mathrm{ml}$ of alkaline-substrate buffer (100 $\mathrm{mM}$ Tris base, 150 $\mathrm{mM}$ Sodium Chloride, $50 \mathrm{mM}$ Magnesium Chloride at $\mathrm{pH}$ 9.5). Levamisole $(10 \mathrm{mg})$ was added to inhibit residual alkaline phosphatase activity. The alkaline phosphatase enzyme activity associated with the probe forms as localized purple precipitate. Colour development was assessed under a phase contrast microscope until purple precipitates could be detected on chromosomes (within $2 \mathrm{~h}$ ). Negative control slides without the probe were prepared in each in situ hybridization experiment.

Hybridization signals which appeared as symmetrical spots on both chromatids of at least one of the two homologous chromosome were recorded as positive. Signals which occurred in fewer than 50\% of the spreads were not recorded. Positive control slides (paraffin-embedded sections of adenovirus type 2-infected Hela cells) were hybridized with positive probe and developed using the same procedures as described for samples to confirm the efficiency of the procedure employed. Photographs for meiotic spreads, mitotic spreads, C-banding and in situ hybridization were taken with Kodak Technical Pan 2415 film, under an oil immersion $(100 \times$ objective $)$ using a Zeiss Carol microscope.

\section{RESULTS}

\section{Meiotic chromosome counts}

Pollen mother cells of A106 showed 17 bivalents in meiotic metaphase 1 (Fig 1A) and a haploid pollen cell contained 17 chromosomes (Fig 1B) confirming that A106 is diploid with a chromosome complement $2 \mathrm{n}=34$.

\section{Mitotic chromosome spreads and C-banding}

Examination of mitotic chromosomes from root tips stained by conventional methods using a 5\% Giemsa solution demonstrated the existance of morphologically similar homologues (Fig 2A). In seven out of 82 karyotypes studied, a pair of satellites were observed at the end of the short arm of chromosome 3 (Fig 2B). In order to identify the homologous pairs of chromosomes, C-banding in 11 karyotypes was studied in detail. Differential staining of C-bands was observed near the telomeric region of the short arm of chromosomes 2, 4 and 14 at a frequency of $72 \%$, 
chromosomes 8 at 54\% and chromosome 6 and 16 at 45\% (Fig 3).

The well separated chromosome-spreads were photographed. Measurements of the length of the short arm (S) and the long arm (L) were taken from enlarged photographs of 16 intact cells. The mean lengths and arm ratios (L/S) are presented in Tab 1. Chromosome size ranged from $1.18 \mu \mathrm{m}$ to $2.82 \mu \mathrm{m}$, and the arm ratio (1.7 to 3). Chromosomes in A106 were all submetacentric based on the criteria of Levan et al[1 9].

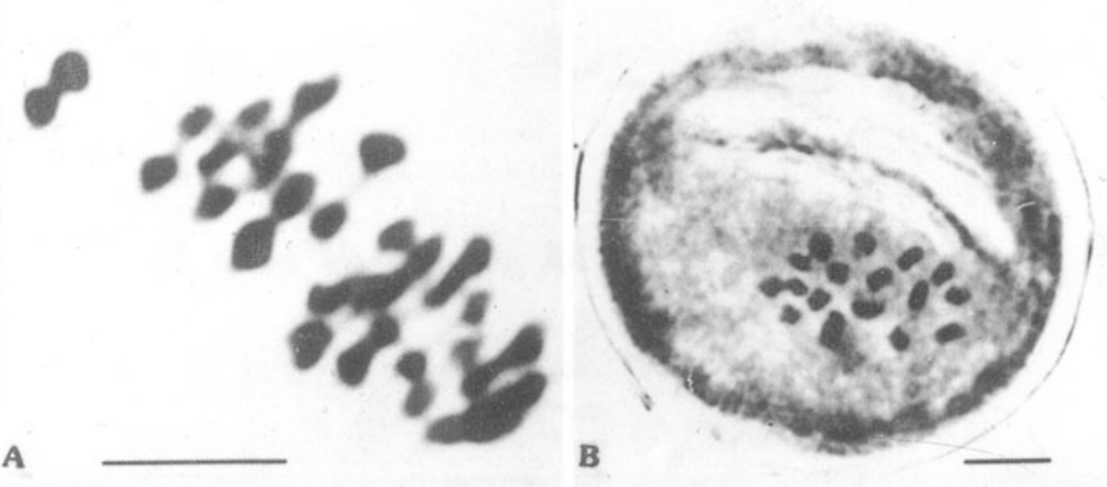

Fig 1. Acetocarmine stained pollen mother cells

(A) 17 bivalents in a diploid pollen mother cell at meiotic metaphase 1 .

(B) 17 chromosomes in a haploid pollen cell of A106 (Malus sieboldii).

In situ hybridization analysis

Hybridization sites for EPG were observed on the long arm of chromosome 14 in all but one of the 16 spreads studied and were proximal to the centromere on chromosomes 6 and 11 in 75\% of the spreads, (Fig 4). An additional 16 spreads studied for ACC oxidase revealed hybridization sites in the telomeric region of the short arm of chromosomes 5 and 11 in $87 \%$ and $81 \%$ of the spreads respectively, proximal to the centromere of chromosome 1 in $81 \%$ of the spreads, and on the long arm of chromosome 13 in 50\% of the spreads (Fig 5). Hybridization sites were observed for ACC synthase in the telomeric region of the short arm of chromosome 12 in $96 \%$ of the spreads studied, chromosomes 9 and 10 in $76 \%$ of the spreads, and chromosome 17 in $56 \%$ of the spreads (Fig 6). Negative control spreads showed no signal or colour reaction, and positive control slides showed strong purple precipitates at the site of Hela cells infected with adenovirus type 2 . 


\section{$\begin{array}{lllllllllllllllll}1 & 2 & 3 & 4 & 5 & 6 & 7 & 8 & 9 & 10 & 11 & 12 & 13 & 14 & 15 & 16 & 17\end{array}$

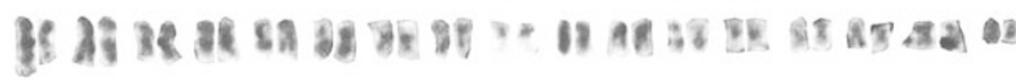

A
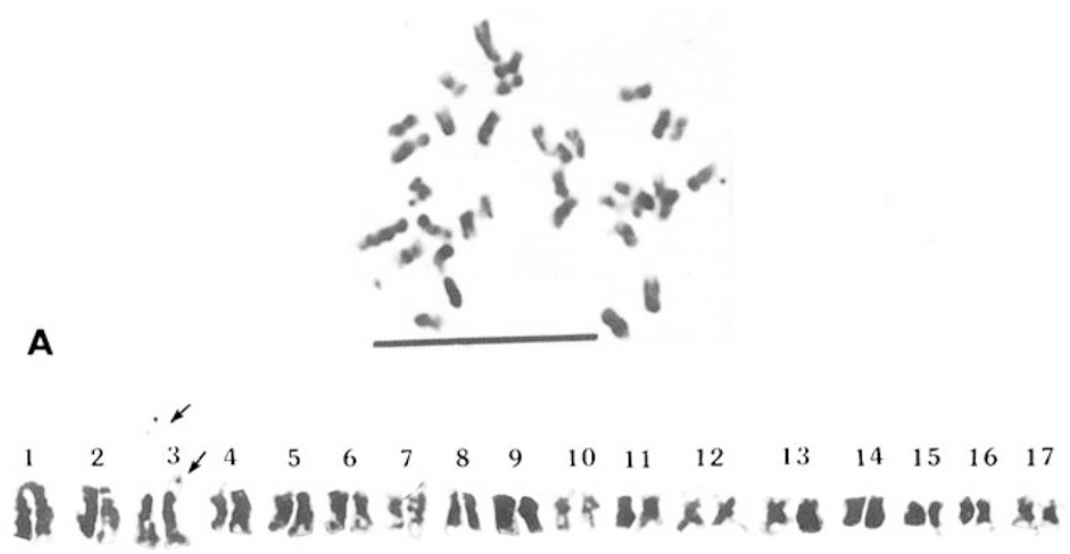

B

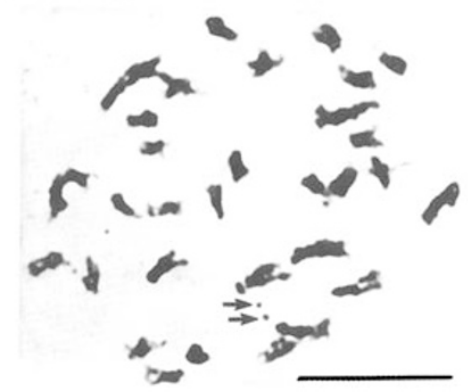

Fig 2. Giemsa stained karyotype of root-tips of A106 (Malus sieboldii)

(A) 17 homologous pairs of chromosomes. Bar $=10 \mu \mathrm{m}$

(B) One pair of satellites showing at the end of the short arm of chromosome 3 (at late prophase). $\mathrm{Bar}=10 \mu \mathrm{m}$
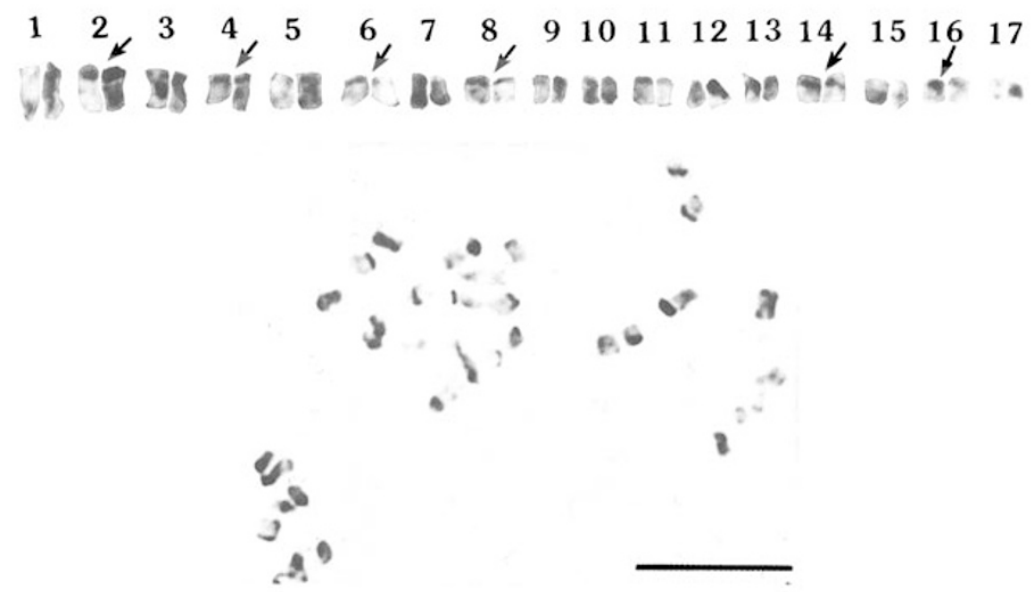

Fig 3. C-banding karyotype of root-tips of A106 (Malus sieboldii). Bar $=10 \mu \mathrm{m}$ 
Zhu JM et al.

\section{$\begin{array}{lllllllllllllllll}1 & 2 & 3 & 4 & 5 & 6 & 7 & 8 & 9 & 10 & 11 & 12 & 13 & 14 & 15 & 16 & 17\end{array}$

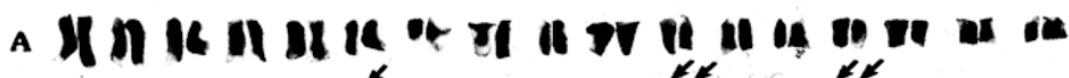

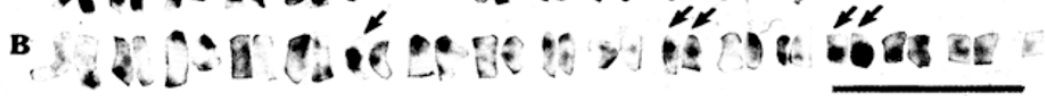

Fig 4. In situ hybridization with biotin labelled $0.6 \mathrm{~kb}$ cDNA of endopolygalacturonase (EPG).

(A) Giemsa stained karyotypes.

(B) In situ hybridization sites of EPG. Bar $=10 \mu \mathrm{m}$.

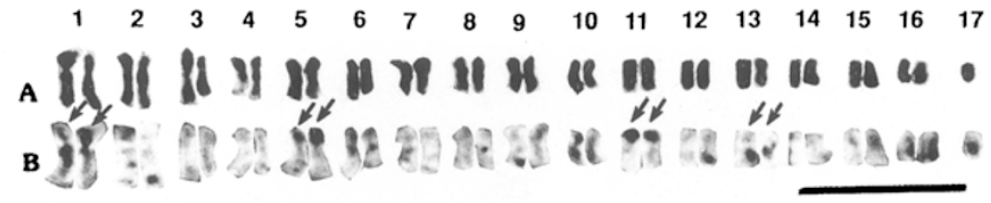

Fig 5. In situ hybridization with biotin labelled 1182 bp cDNA of ACC exidase.

(A) Giemsa stained karyotypes.

(B) In situ hybridization sites of ACC oxidase. Bar $=10 \mu \mathrm{m}$.

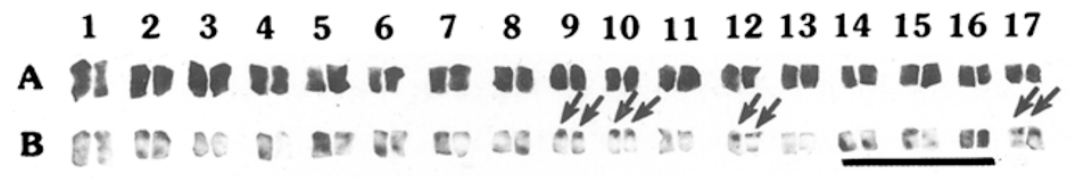

Fig 6. In situ hybridizatioil with biotin labelled $2 \mathrm{~kb} \mathrm{cDNA}$ of ACC synthase.

(A) Giemsa stained karyotype.

(B) In situ hybridization situs of ACC synthase. Bar $=10 \mu \mathrm{m}$.

\section{DISCUSSION}

It is reported that Malus sieboldii has a diploid chromosome number $2 \mathrm{x}=34,3 \mathrm{x}$ $=51,4 \mathrm{x}=68$ and $5 \mathrm{x}=85$ [20]. In New Zealand, analysis of the apple rootstock Malus sieboldii A106 demonstrated that it has a haploid chromosome number of 17 and a diploid chromosome number $2 \mathrm{n}=34$ based on chromosome counts of meiotic metaphase pollen mother cells, the pollen cell, and mitotic chromosome spreads 
of root-cells. A small pair of satellites was sometimes observed on one or both of the homologues of chromosome 3. The low frequency appearance of satellites is probably caused by the poor quality of spreads and the relatively small size of the apple chromosome $(1.18-2.82 \mu \mathrm{m})$. Late prophase and early metaphase root-tip cells with the least cytoplasm produced the best mitotic chromosome spreads for karyotyping.

Tab 1. Mitotic measurements for apple rootstock 'A106' (Malus sieboldii)

(Mean of sixteen somatic chromosomes)

\begin{tabular}{ccc}
\hline Chromosome number & Relative length & Arm ratio \\
\hline 1 & 9.21 & 2.04 \\
2 & 7.93 & 2.15 \\
3 & 7.40 & 2.06 \\
4 & 6.97 & 2.14 \\
5 & 6.63 & 2.17 \\
6 & 6.26 & 1.86 \\
7 & 6.09 & 1.75 \\
8 & 5.83 & 2.14 \\
9 & 5.58 & 1.83 \\
10 & 5.45 & 1.97 \\
11 & 5.26 & 2.01 \\
12 & 5.09 & 1.96 \\
13 & 4.91 & 1.98 \\
14 & 4.68 & 1.84 \\
15 & 4.49 & 1.98 \\
16 & 4.36 & 1.96 \\
17 & 3.87 & 1.81 \\
\hline
\end{tabular}

All chromosomes are submetacentric according to the criteria of Levan et al (1964)

The differential staining technique of C-banding was used for the first time in apple to identify pairs of homologous chromosomes. C-bands at the terminal regions of the short arm of chromosomes 2, 4, 14 were apparent in more than $70 \%$ of the spreads and at the terminal region of chromosome 8 in more than $50 \%$ of the spreads. C-bands were apparent in fewer than $50 \%$ of spreads at the terminal regions of the short arm of chromosomes 6, 7, and 16. Centromeric C-bands were detected during prophase on chromosomes 7, 10 and 13 in only 2 of 16 karyotypes, and no other C-bands were detected in this study. C-bands are thought to represent highly repeated DNA sequence or heterochromatin regions which can be used in some chromosome karyotypes as markers to identify individual chromosomes. This information can then be used for in situ hybrization studies. In apple it is apparent that C-banding, on its own, is not sufficient to distinguish all 17 homologues or for detailed localization of genes on chromosomes, but it may be useful in distinguishing certain chromosomes which are similar in size and arm ratio (e.g. chromosomes 4 and 5). 
Tab 2. EPG, ACC oxidase and ACC synthase hybridization sites on A106 chromosomes

\begin{tabular}{|c|c|c|c|}
\hline \multirow[t]{2}{*}{ Chromosome number } & \multicolumn{2}{|c|}{ Gene location } & \multirow[b]{2}{*}{ ACC synthase (25) } \\
\hline & EPG ( 16 spreads ) & ACC Oxidase (16) & \\
\hline 1 & \multirow{4}{*}{\multicolumn{3}{|c|}{ Proximal (81\%) }} \\
\hline 2 & & & \\
\hline 3 & & & \\
\hline 4 & & & \\
\hline 5 & \multirow{4}{*}{ Proximal $(75 \%)$} & \multirow[t]{6}{*}{$\mathrm{NT}(\mathrm{S})(87 \%)$} & \\
\hline 6 & & & \\
\hline 7 & & & \\
\hline 8 & & & \\
\hline 9 & \multirow{5}{*}{ Proximal $(75 \%)$} & & NT (S) $(76 \%)$ \\
\hline 10 & & & NT (S) $(76 \%)$ \\
\hline 11 & & \multirow{2}{*}{ NT (S) $(81 \%)$} & \\
\hline 12 & & & NT (S) $(96 \%)$ \\
\hline 13 & & L $(50 \%)$ & \\
\hline 14 & \multirow{4}{*}{ Proximal L ( > 94\%) } & & \\
\hline 15 & & & \\
\hline 16 & & & \\
\hline 17 & & & NT (S) $(56 \%)$ \\
\hline
\end{tabular}

EPG: endopolygalacturonase

Proximal: Proximal to the centromere

L: Long arm

NT: Near the telomeric region

S: Short arm

The gene expression and regulation of the enzymes EPG, ACC oxidase and ACC synthase have been shown to be important in the ripening of a number of fruit[21]. In apple, Southern analysis has produced evidence that these enzymes are encoded by multigene families[16, 17, 22, 23]. Through in situ hybridization, the present study indicates that genes homologous to EPG, ACC oxidase and ACC synthase are located in different regions on a total of 10 pairs of chromosomes. Genes homologous to EPG were located on three different chromosomes, and those homologous to ACC oxidase and ACC synthase were each located on four different chromosomes (Tab 2). Location of different members of multigene families on separate chromosomes has also been demonstrated for the ACC synthase multigene family in tomato[24]. The results in the present work demonstrate that a Streptavidin conjugated alkaline phosphatase detection system can be used to locate genes on an apple karyotype by in situ hybridization.

Other methods of in situ hybridization have used fluorescein as a non-isotopic reporter system to detect hybridization signals in plants such as wheat[1, 25], Allium[26], soybean[27] sugar beet[28] and Solanum brevidens[29]. Fluorescence in situ hybridization (FITC) and chromosome banding in humans were successfully integrated into a single procedure[30]. DNA sequences can be directly and precisely mapped to a specific chromosome area by combining these techniques[l, 31]. Fluoresence-banding using dyes such as DAPI has been recently reported in citrus 
by Guerra[32] who demonstrated the existence of heterochromatin at the terminal region of long arms. A different banding pattern was apparent in each species. A similar approach using fluorescent dyes might be possible in apple chromosomes and any markers revealed would be useful for chromosome identification. An alternative approach that could be taken is to use the simultaneous visualization of in situ hybridization signals for single genes and a suitable method for producing banding patterns with fluorescent dyes or fluorescently labelled repeated DNA. This might enable more precise physical mapping of genes in apple and increase the efficiency of map construction.

\section{REFERENCES}

[1] Jiang J, Gill BS. Sequential chromosome banding and in situ hybridization analysis. Genome 1993; 36:792-5.

[2] Simpson PR, Newman MA, Davis DR. Detection of legumin gene DNA sequences in pea by in situ hybridization. Chromosoma (Berl) 1988; 96:454-8.

[3] Murray BG, Bennett MD, Hammett KRW. Secondary constrictions and NORs of lathyrus investigated by siver staining and in situ hybridization. Heredity 1992; 68:473-8.

[4] Lapitan NLV, Ganal MW, Tanksley SD. Organization of the 5S ribosomal RNA genes in the genome of tomato. Genome 1991; 34:509-14.

[5] Zhu JM, Gardiner SE. Chromosomal localization of ribosomal DNA sequences in an apple rootstock using a digoxygenin detection system. Cell Research (1995); 5(1):1-7.

[6] King G J, Alston FH, Battle I, Chevreau E, Gessler C, Janse J, Lindhout P,Manganaris AG Sansavini S, Schmidt H, Tobutt K. "The European apple genome mapping project' - developing a strategy for mapping genes coding for agronomic characters in tree species. Euphytica 1991; 56: 89-94.

[7] Hemmat M, Weeden NF, Manganaris AG, Lawson DM. Molecular marker linkage map for apple. J Hered, 1994; 85(1):4-11.

[8] Gardiner SE, Zhu JM, Whitehead HCM, Madie C. The New Zealand apple genome mapping project. Euphytica (1994); 77:77-81.

[9] Lespinasse Y, Alston FH, Watkins R. Cytological techniques for use in apple breeding. Ann Appl Biol 1976; 82:349-53.

[10] Schweizer D. Differential staining of plant chromosomes with Giemsa. Chromosoma (Berl) 1973; 40:307-20.

[11] Sumner AT. A simple technique for demonstrating centromeric heterochromatin. Exp Cell Res 1972; 75:304-6.

[12] Seal AG, Bennett MD. Preferential C-banding of wheat or rye chromosomes. Theor Appl Genet 1982; 63:227-33.

[13] Kakeda K, Fukui K, Yanmgata H. Heterochromatic differentiation in barley chromosomes revealed by C- and N- banding techniques. Theor Appl Genet 1991; 81:144-50.

[14] Heneen WK, Brismar K. Rye heterochromatin in the somatic chromosome of triticale in relation to grain shrivelling. Hereditas 1987; 107:137-45.

[15]MacGregor HC, Varley JM. Chapter 4 Chromosome banding. In: Working with animal chromosomes. John Wiley and Son Ltd Chichester, New York, Brisbane, Toronto, Singapore. 1983: p 70-96

[16]Ross GS, Knighton ML, Lay-Lee M. An ethylene-related cDNA from ripening apples. Plant molecular Biology 1992; 19:231-8.

[17]Lay-Yee M, Knighton ML. A full-length cDNA encoding 1-aminocyclopropane-1-carboxylic synthase from apple. Plant Physiol 1995; 107:1017-8. 
[18] Emanuel JR. Simple and efficient system for synthesis of non-radioactive nucleic acid hybridization probes using PCR. Nucleic Acids Research 1991; 19(10):2790.

[19] Levan A, Predga K, Sandberg AA. Nomenclature for centromeric position on chromosomes. Hereditas 1964; 52:201-20.

[20] Chen RY. Chromosome atlas of chinese principal economic plants. Tonms I, Chromosome atlas of chinese fruit trees and their close wild relatives. Chen RY Ed. 1993.

[21] Dilley DR, Wilson ID. Molecular biological investigations of gene expression attending fruit ripening: Current status and future prospects. Hort Technology 1992; 2(3):294-301.

[22] Atkinson RG. Molecular approaches to horticultural crop improvement. PhD Thesis, University of Auckland, Auckland, New Zealand 1993.

[23] Dong JG, Kim WT, Yip WK, Thompson GA, Li L, Bennett AB, fang SF. Cloning of a cDNA enxoding l-aminocyclopropane-1-carboxylic synthase and expression of its mRNA in ripening apple fruit. Planta 1991; 185:38-45.

[24] Rottman WH, Peter GF, Oeller PW, et al. 1-aminocyclopropane-1-carboxylate synthase in tomato is encoded by a multigene family whose transcription is induced during fruit and floral senescence. J Mol Biol 1991; 222:937-61.

[25] Schwarzacher T, Anamthawat-J onsson K, Harrison GE, et al. Genomic in situ hybridization to identify alien chromosomes and chromosome segments in wheat. Theor Appl Genet 1992; 84:778-86.

[26] Ricroch A, Peffley EB, Baker RJ. Chromosomal location of rDNA in Allium: in situ hybridization using biotin- and fluorescein-labelled probe. Theor Appl Genet 1992; 83:413-8.

[27] Griffor MC, Vodkin LO, Singh R J, Hymowitz T. Fluorescent in situ hybridization to soybean metaphase chromosomes. Plant Molecular Biology 1991; 17: 101-9.

[28] Schmidt T, Schwarzacher T, Heslop-Harrison JS. Physical mapping of rRNA genes by flourescent in situ hybridization and structural analysis of $5 \mathrm{~S}$ rRNA genes and intergenic spacer sequences in sugar beet (Beta vulgaris) Theor Appl Genet 1994; 88:629-36.

[29] Preiszmer J, Takacs I, Bilgin M, Gyorgyey J, Dudits D, Feher A. Organization of a Solanum brevidens repetitive sequence related to the TGRI subtelomeric repeats of Lycopersicon esculentum. Theor Appl Genet 1994; 89:1-8.

[30] Fan YS, Davis LM, Shows TB. Mapping small DNA sequences by fluorescence in situ hybridization directly on banded metaphase chromosomes. Proc Natl Acad Sci USA 1990; 87: 6223-7.

[31] Heng HHQ, Tsui L-C. Modes of DAPI banding and simultaneous in situ hybridization. Chromosoma 1993; 102:325-32.

[32] Guerra, M. Cytogenetics of Rutaceae. V. High chromosomal variability in Citrus species revealed by CMA/DAPI staining. Heredity 1993; 71:234-41.

Received 29-9-1995. Revised 20-11-1995. Accepted 6-12-1995 